\title{
The Lives and Afterlives of the Library of the Maronite Physician Ḥannā al-Ṭabīb (c. 1702-1775) from Aleppo
}

\author{
Feras Krimsti \\ University of Oxford \\ feras.krimsti@history.ox.ac.uk
}

\begin{abstract}
In eighteenth-century Aleppo, books acquired an unprecedented significance among Aleppo's Christians, against the background of an expanding "culture of the book". This paper attempts to reconstruct the library of the Maronite physician Hannā alṬabīb (c. 1702-1775), based on ownership statements in manuscripts purchased by the German scholar and Oriental traveller Ulrich Jasper Seetzen (1767-1811) in Aleppo, presently preserved in Gotha's Research Library. Proceeding from an assessment of the ownership statements and a thematic analysis of the library, the paper will address the implications for our understanding of book ownership in the social and intellectual milieu of the owner. It will be argued that owning books was a facet of an intensifying and active — not passive—preoccupation with literature among Christians.
\end{abstract}

\section{Keywords}

Arabic manuscripts - library history - book culture - marginalia - ownership statements - Ottoman Aleppo - Eastern Christianity

\section{Bibliophilism among Christians in Eighteenth Century Aleppo ${ }^{1,2}$}

During the eighteenth century, Aleppo witnessed an expanding "culture of the book." As Bernard Heyberger has shown, books acquired an unprecedented sig-

1 Submitted February 19, 2018. Accepted for publication March 30, 2018.

2 I would like to thank the Gotha Research Centre of the University of Erfurt for supporting

(C) FERAS KRIMSTI, 2018 | DOI:10.1163/1878464X-00902006

This is an open access article distributed under the terms of the prevailing CC-BY-NC license at the time of publication. 
nificance among Aleppo's Christians. ${ }^{3}$ He pointedly calls this phenomenon an "enchantment with books" ("engouement pour le livre"). ${ }^{4}$

This development had a long pre-history. The Reformation had pushed Rome to launch an editorial project in the sixteenth century to reach Eastern Christianity. The printing press of the Congregatio de Propaganda Fide produced Arabic and Syriac prints to be used by missionaries and to be diffused among Oriental Christians - mostly liturgical and linguistic works. The control over matters of belief the Catholic Church was able to exert through printing led to theological problems, however. ${ }^{5}$ Contentious issues touched on the very identity of Arabic Christians. Heyberger argues that both the creation and diffusion of local printing presses - for example, the famous printing press of the Catholic Melkite monks of Dayr al-Shuwayr, which has been extensively researched ${ }^{6}$ — and the revival of manuscripts, which remained cheaper in production, offered Oriental Christians a certain autonomy to express their own views. $^{7}$

my research on Ḥannā al-Ṭabīb with a Herzog Ernst Scholarship both in July and August 2o11, and in November and December 2015, and Dr John-Paul Ghobrial for his helpful comments on earlier versions of this paper. This paper draws on research conducted for the project Stories of Survival: Recovering the Connected Histories of Eastern Christianity in the Early Modern World, which is supported by funding from the European Research Council (ERC) under the European Union's Horizon 2020 research and innovation programme (grant agreement number 638578$)$.

3 See Bernard Heyberger, "Livres et pratique de la lecture chez les chrétiens (Syrie, Liban). XVII ${ }^{\mathrm{e}}-\mathrm{XVIII}{ }^{\mathrm{e}}$ siècles," Revue des Mondes Musulmans et de la Méditerranée 87-88 (1999): 209223 .

4 Heyberger, "Livres," 215.

5 See Heyberger, "Livres," 210-213.

6 See especially Carsten-Michael Walbiner, "Die Protagonisten des frühen Buchdrucks in der arabischen Welt," in Das gedruckte Buch im Vorderen Orient, ed. U. Marzolph (Dortmund: Verlag für Orientkunde, 2002), 128-141, on the beginnings of Arabic printing. For the establishment of a printing press in al-Shuwayr by 'Abdallāh Zākhir (168o-1748), see ibid., 132-138. On 'Abdallāh Zākhir, see Paul Bacel, "Abdallah Zakher. Ses premiers travaux (168o-1722)," Échos d'Orient 11.71 (1908): 218-226, id., "Abdallah Zakher et son imprimerie arabe," Échos d'Orient 11.72 (1908): 281-287, and id., "Dernières années d'Abdallah Zakher," Échos d'Orient 11.73 (1908): 363-372. John-Paul Ghobrial, "The Ottoman World of 'Abdallah Zakher. Shuwayr Bindings in the Arcadian Library," in The Arcadian Library: Bindings and Provenance, ed. G. Mandelbrote and W. de Bruijn (London: Arcadian Library/Oxford University Press, 2014), 193-231, has recently shown that the initiation of the Shuwayr project was possible only through a network of relations unfolding across the Ottoman World, the establishment of the printing press therefore being an "Ottoman affair," too.

7 See Heyberger, "Livres," 213-215. 
The enchantment with books simultaneously opened up literary horizons, in monastic circles but also well beyond. Heyberger emphasizes the presence of book lovers in the milieu of merchants in particular. ${ }^{8}$

The Natural History of Aleppo, authored by Alexander Russell (1715-1768) and significantly expanded by his brother Patrick Russell (1726-1805), both physicians and long-term residents of Aleppo, sheds light on this fascination with manuscripts in Aleppo-particularly among affluent merchants:

It has of late become a fashion among the opulent merchants to collect books [...]. The fashion in the mean while (founded on the mere pride of possession) has greatly raised the value of manuscripts; for the Sheihs [sic], who used formerly to be almost the only bidders at auctions, and who are unable to contend with rich competitors, are now in a great measure excluded as purchasers. ${ }^{9}$

Libraries and book collections had become a prominent feature of intellectual life in the Levant. In Christian circles, they were to be found in convents and monasteries. The scholar, explorer and traveller Ulrich Jasper Seetzen (1767-1811) notes that Arabic grammatical and lexicographical works could be found "in every convent" and that they were used by the monks to perfect their linguistic skills. ${ }^{10}$ While Seetzen does not refer to libraries in the strict sense, his observation points to a general presence of books in monastic milieus.

However, laypersons among the Christians collected books, too, and gathered substantial book collections and libraries. The Protestant missionary Stephan Schultz, who travelled through the Ottoman Empire between $175^{2}$ and 1756 and also visited Aleppo, mentions the collection of books of the eldest son of Ni'mat, the dragoman of the Dutch consulate:

Afterwards, Mr. Namet took us to his house and showed us the library of his eldest son, which consists of several Arabic, Persian, and Turkish

8 See Heyberger, "Livres," 219.

9 Alexander Russell, revised, enlarged, and illustrated with notes by Patrick Russell, The Natural History of Aleppo: Containing a Description of the City, and the Principal Natural Productions in its Neighbourhood. Together with an Account of the Climate, Inhabitants, and Diseases, particularly of the Plague, 2 vols. (London: G.G. and J. Robinson, 1794 [Second edition]), vol. 2, 95 .

10 See Ulrich Jasper Seetzen, Tagebuch des Aufenthalts in Aleppo 1803-1805, ed. J. Zepter, C. Walbiner and M. Braune (Hildesheim: Olms, 2011), 73. 
books, but in particular Syriac ones, and also many in the Arabic language with Syriac letters, which they call Kerschuni [karshūnī ].11

It is little known that by far the largest library owned by one of Aleppo's Christians and his family that we can still reconstruct to some degree today belonged to the Maronite physician Hannā al-Tabỉb (c. 1702-1775). The present article is concerned with this library and the history of its dissolution. It will attempt to partially reconstruct the library and investigate into its implications for our understanding of the intellectual world of Christians in eighteenth-century Aleppo. It will also inquire into the profile of a Christian readership. Hannā alTabib's library reveals an active engagement with literature in the physician's milieu and an intellectual curiosity that finds expression in the library's wide thematic spectrum. This bibliophilism not only took root among affluent Christians in early modern Aleppo but is also tied to similar developments on the regional and, above all, the imperial scale.

As is the case for many early modern authors of chronicles and travelogues, little is known about Ḥannā. It is rather curious that Ḥannā is not mentioned in major reference works as the author of a travelogue, neither by Louis Cheikho, nor by Georg Graf. ${ }^{2}$ The latter probably limited his research to those sections of European catalogues that were devoted to "Christian literature" thus missing the travelogue.

Fortunately, Hannā's travelogue came to the attention of the physician and traveller Ulrich Jasper Seetzen. Having studied medicine and natural history at the University of Göttingen, the latter set out on a journey to the Orient in 1803, motivated by the expeditions of the explorers of his time, notably Alexander von Humboldt (1769-1859), who counted among his friends. With the financial support of Herzog Ernst II of Saxony-Gotha-Altenburg (1745-1804), Seetzen travelled through the Ottoman Empire, Syria, Palestine, Egypt, the Hijāz, purchasing and gathering manuscripts and orientalia for the Herzog's collection. He stayed in Aleppo for one year and four months, around thirty years after the death of Ḥannā al-Ṭabīb. Seetzen's journey finally came to a dramatic end in Yemen, where he was killed. ${ }^{13}$

11 See Stephan Schultz, Der Leitungen des Höchsten nach seinem Rath auf den Reisen durch Europa, Asia und Africa, 5 vols. (Halle: Carl Hermann Hemmerde, 1771-1775), vol. 5, 49. Partial translation by Jan Schmidt, "The Journey of Stephan Schultz, Protestant Missionary from Halle, in the Ottoman Empire 1752-1756," Oriens 39 (2011): 17-57, 53.

12 See Louis Cheikho, Kitāb al-Makhțūțāt al-'arabiyya li-katabat al-nașrāniyya (Beirut: Imprimerie Catholique, 2000 [reprint of the original from 1924]), 125, for a single mention of Arsāniyūs brother "the priest Shukrī." He is not mentioned at all in any volume of Graf's, Geschichte der christlichen-arabischen Literatur.

13 On Seetzen's biography, his milieu, and his journey see especially Detlef Haberland, 
Seetzen provides key information about Ḥannā and his brother Arsāniyūs in his "Nachrichten von einigen Arabischen, Persischen und Türkischen Reisebeschreibungen, Topographien und andern geographischen Werken und Landkarten," published in 1805 in the Journal Monatliche Correspondenz zur Beförderung der Erd-und Himmelskunde. In the article, Seetzen wrote about Hannä's travelogue and other works with the intention to bring Arabic, Ottoman, and Persian travelogues and geographical works to the attention of the European scientific community "in order to enrich our knowledge (zur Bereicherung unserer Kenntnisse)."14

Seetzen does not mention from which sources he drew the account of the physician's life. According to the German traveller, Hannā was born around 1702 as the son of a Maronite physician. ${ }^{15}$ His younger brother Jurjī b. Shukrī al-Ḥakīm (later Arsāniyūs) was born in 1707. While Ḥannā, following in the footsteps of his father, became physician, Jurji chose a career in the church. ${ }^{16}$ Ḥannā was the protégé of the serasker Köprülü Abdullah Pasha and accompanied him during the Ottoman-Persian war. ${ }^{17} \mathrm{He}$ survived the defeat of the latter and ultimately returned to Aleppo, where he became an acclaimed physician. Seetzen mentions vaguely that Hannā was acquainted with one of the Russell brothers. Neither Alexander, nor Patrick Russell, however, mentions Ḥannā in any of the Russells' letters and publications.

Except for the eight months of Hannā's journey to the capital of the Ottoman Empire and back (1764-1765), about which we know more from the physician's travelogue (rihla), ${ }^{18}$ the sources are mostly silent about him. Seetzen only mentions that he died in Aleppo in 1775, aged 73. ${ }^{19}$

According to the travelogue, a lengthy narrative in a style of Arabic that some scholars have referred to as "Middle Arabic," which is also strongly characterized by a multitude of Ottoman loan words, the physician was ordered

"Ulrich Jasper Seetzen-Ein Leben für eine Forschungsreise in den Vorderen Orient und auf die Arabische Halbinsel," in Ulrich Jasper Seetzen, Tagebuch des Aufenthalts in Aleppo 1803-1805 (Hildesheim: Olms, 2011), XIII-XL. See the comments on Herzog Ernst II's financial support, ibid. XXII-XXIII.

14 See Ulrich Jasper Seetzen, "Nachrichten von einigen Arabischen, Persischen und Türkischen Reisebeschreibungen, Topographien und andern geographischen Werken und Landkarten," Monatliche Correspondenz zur Beförderung der Erd- und Himmelskunde 12 (August 1805): 101-125, 102.

15 See Seetzen, "Nachrichten," 120.

16 See Seetzen, "Nachrichten," 105-106, 109.

17 See Seetzen, "Nachrichten," 110-111.

18 See Ms. Orient. A 1550. The text has no title, but starts with the words naktub rihlat alshammās Hannā al-Ṭabìb ilā baldat Istanbūl.

19 See Seetzen, "Nachrichten," 120. 
to Istanbul by the Grand vizier for a treatment of the şeyhülislam, who had become sick. While travelling, Hannā wrote down his experiences and observations on daily life in the Ottoman capital as well as in the towns and villages on his way. His travelogue is rich with comments on nature, food, celebrations, and customs, curious stories and anecdotes, and occasional accounts of political events. ${ }^{20}$

This article offers only a preliminary study of Ḥannā's library in preparation for a larger monograph I am now completing on the subject of Hannās library and the culture of the book in eighteenth-century Aleppo. The study will also contain a complete list of all the books belonging to Ḥannā and his family. ${ }^{21}$

\section{$2 \quad$ Reconstructing a Family Library with Ownership Statements}

Scholarly interest in historical libraries and book collections in the Near East and Ottoman Syria in particular has recently grown. For example, Konrad Hirschler has studied the content and structure of the earliest mediaeval library of the Middle East for which a catalogue has survived, the Ashrafiyya of Damascus. ${ }^{22}$ Boris Liebrenz has shed light on the so-called Rifāiiyya, bought by Johann Gottfried Wetzstein (1815-1905) in Damascus and sent in its entirety to Leipzig in 1853 . He has reconstructed the history of the purchase, thematic spectrum of the library, its intellectual milieu and the readership. In the framework of his engagement with the Rifăciyya, Liebrenz has also reconstructed the library of Ahmad al-Rabbāt (d. after 1252/ 1836-1837), parts of which came to be integrated into the Rifā'iyya. ${ }^{23}$ Especially in Liebrenz' work, manuscript notes in

$20 \quad$ An edition and translation of the travelogue are currently in preparation.

21 Preliminary work includes the chapter devoted to the library and Aleppo's culture of the book in my dissertation. See Feras Krimsti, Der Istanbul-Reisebericht des Aleppiner Arztes Hannā ț-Ṭabib (1764/65): Alltagsbilder und identitäre Verortungen (PhD thesis Berlin, 2016), 59-79. Some remarks on this family library can also be found in Boris Liebrenz, Die Rifā‘ ‘̄ya aus Damaskus: Eine Privatbibliothek im osmanischen Syrien und ihr kulturelles Umfeld (Leiden: Brill, 2016), 249-25o, 340-341.

22 See Konrad Hirschler, Medieval Damascus: Plurality and Diversity in an Arabic Library: The Ashrafiya Library Catalogue (Edinburgh: Edinburgh University Press, 2016).

23 On Aḥmad al-Rabbāț’s library in particular see Boris Liebrenz, "Die Rifāīìa. Neue Forschungen zur Geschichte einer Familienbibliothek aus dem osmanischen Damaskus," in Das Buch in Antike, Mittelalter und Neuzeit: Sonderbestände der Universitätsbibliothek Leipzig, ed. Th. Fuchs, Ch. Mackert and R. Scholl (Wiesbaden: Harrassowitz, 2012), 265277, 277-279, id., Die Rifā čya, 116-117, id., "The Library of Aḥmad al-Rabbāț: Books and their Audience in 12th to 13th/18th to 19th Century Syria," in Marginal Perspectives on EarlyModern Ottoman Culture: Missionaries, Travellers, Booksellers, ed. U. Pietruschka and 
manuscripts play a crucial role, for example in discussions of the price of books or with regard to the reconstruction of the library's readership.

Frequently, existing catalogues on Arabic manuscripts do not mention secondary notes; this silence on important aspects of the cultural history of the book and attendant philological practices makes it important to return to the manuscripts themselves.

Ownership statements-mostly in manuscripts today preserved in the Gotha Research Library—enable us to reconstruct Ḥannā al-Ṭabīb’s library in the first place. The manuscripts that contain such ownership statements were transferred to Gotha after they had been purchased by Ulrich Jasper Seetzen, who summarizes his activities in Aleppo as follows:

I am always very busy here and have more work than I am able to do. I have had a Maronite who taught me the Arabic language, I wrote down conversations in Arabic, have collected poems, sayings, idiomatic expressions, riddles and I have gathered information on all interesting topics pertaining to the city. I have made huge purchases for the Oriental Collection in Gotha $[\ldots] .{ }^{24}$

Seetzen probably sent Hannā's manuscripts to Gotha in five boxes along with other manuscripts and objects that he had bought. He mentions the boxesthough not the physician's name-in his diary in an entry dated February 11, $1805 .{ }^{25}$ Interestingly, earlier in his diary, he offers a summary and translation into German of the beginning of Hannā al-Ṭabīb's riḥla. The last dated entry before this section was written on October $7,1804 .{ }^{26}$ This suggests that Seetzen must have come into the possession of the manuscript at this point and that it was still a topic of immediate relevance for him.

There are at least two scenarios that might explain how Seetzen came into possession of Hannā's library. Seetzen could have bought the library directly from a member of Hannā's family (perhaps one or several of his sons). In his diary, he never mentions a family member and although he might have had his information about Ḥannā and Arsāniyūs from this family member, we cannot

R. Elger (Halle:Zentrum für Interdisziplinäre Regionalstudien, Universität Halle, 2013), 1759 .

24 See Ulrich Jasper Seetzen, “Doktor Seetzen's Reisenachrichten," Intelligenzblatt von Salzburg, 14 December 1805: 782-787, 785 (translation mine).

25 See Seetzen, Tagebuch des Aufenthalts in Aleppo, 295-296.

26 Seetzen, Tagebuch des Aufenthalts in Aleppo, 213 (last dated diary entry before the summary/ translation) and 223-227 (summary/ translation). 
be sure. Both were renowned members of the Maronite community in Aleppo, so others were likely to be able to inform Seetzen about the brothers as well.

The second scenario is that Seetzen purchased the library from a local bookseller. In his diary, he mentions "numerous Muslim booksellers,"27 but, more importantly, a Maronite bookseller in the quarter al-Judayda from whom he purchased, for example, books printed in al-Shuwayr on Mount Lebanon and in Aleppo. ${ }^{28} \mathrm{He}$ identifies him later by name as Shammās Ya'qūb. ${ }^{29}$ If, indeed, Seetzen bought the library from a local bookseller, it would be striking that 73 manuscripts from one family collection were available for sale at the same time.

Be this as it may, we can be sure that Seetzen did not buy the complete book collection of the family; as described below, a small number of the family's manuscripts were not transferred to Gotha, but rather ended up in collections in Aleppo and Beirut. We can also be relatively sure that we are confronted with the dissolution of a family library, given the extraordinary number of books that were sold. It is rather improbable that many more books remained in the possession of the family. But why was it dissolved? And was it sold by three or four sons simultaneously? Or had it meanwhile been unified in the hand of one family member, perhaps because of the death of some of the sons?

Whatever the answer may be, it seems plausible that economic motivations might have played a role in the decision to sell the library - in the case of the slightly later Rifāìya library, the selling of an entire collection to Europeans who had significant purchasing power, promised and brought high gains. ${ }^{30}$ Perhaps the political turbulences and episodes of unrest in Aleppo at the beginning of the nineteenth century prompted the owner(s) to sell the library of Ḥannā alTabïb and his sons. ${ }^{31}$

27 See Seetzen, Tagebuch des Aufenthalts in Aleppo, 72: "etliche mohammedanische Buchhändler." He reports ibid., 20o, that he was acquainted with three of them, but that they had only Islamic religious literature. Later, he mentions purchases from a certain Muhammad al-Ashrafî ("Mohammed el éschraphy"), see ibid., 230 and 248.

28 See Seetzen, Tagebuch des Aufenthalts in Aleppo, 200.

29 See Seetzen, Tagebuch des Aufenthalts in Aleppo, 210.

30 See Liebrenz, Die Rifǟiya, 72-78. See also John-Paul Ghobrial, "The Archive of Orientalism and its Keepers: Re-Imagining the Histories of Arabic Manuscripts in Early Modern Europe," Past and Present (2016), Supplement 11: 90-111, especially 97-98, for further major purchases of entire collections by European collectors.

31 See Michael Braune, "Ulrich Jasper Seetzens Leben in der Community der Franken in Aleppo (1803-1805)," in Ulrich Jasper Seetzen (1767-1811): Jeveraner-aufgeklärter Unternehmer — wissenschaftlicher Orientreisender, ed. D. Haberland (Oldenburg: Isensee, 2014), $167-185,184-185$, on how Ulrich Jasper Seetzen experienced the political turmoil in Aleppo. 
Seetzen bought manuscripts not only in Aleppo, but in different cities in the Levant and beyond. And yet, to this date, no list of his purchases in Aleppo has been discovered. ${ }^{32}$ Books can therefore only be identified as Hannā's if they bear ownership statements to this effect. Nineteenth-century catalogues do not mention and quote marginalia extensively - it therefore comes as no surprise that Wilhelm Pertsch's Die orientalischen Handschriften der Herzoglichen Bibliothek zu Gotha does not consistently quote Ḥannā's and his relatives' ownership statements. ${ }^{33}$ However, Pertsch does indicate the origin of the manuscriptsin the case of Aleppo, "Haleb." Based on a search of the relevant manuscripts from Aleppo (both the originals and microfilms) in Gotha's Research Library, I was able to identify manuscripts that were originally part of the library of Hannā's family. New online search tools such as databases that concentrate on or at least mention marginalia in manuscripts promise to facilitate similar endeavors in the future. ${ }^{34}$

Further manuscripts that belonged to Ḥannā and his immediate relatives can be traced outside of the Gotha collection as well—notably in the Fondation Georges et Mathilde Salem in Aleppo and in the Bibliothèque Orientale in Beirut. In the case of the former, the identification of manuscripts belonging to Hannā's family relies on an occasional reference to ownership statements in the catalogue..$^{35}$ The reading room provided by the Hill Museum and Manuscript Library offered an invaluable tool for reviewing ownership statements (not mentioned in catalogues) in a large number of manuscripts there and in the collection of the Bibliothèque Orientale especially. ${ }^{36}$

32 Seetzen wrote a "Catalogue of the Oriental Manuscripts purchased in Halep" ("Catalog der in Halep angekauften Orientalischen Manuscripte") and sent it to Franz Xaver von Zach. Seetzen says so himself in one of his letters. See id., "Doktor Seetzen's Reisenachrichten," 786. The fact that Seetzen sent the "Catalogue" together with his contribution "Nachrichten," (which includes Hannā's biography and the paraphrase of the beginnings of his rịhla), later published by von Zach, proves that it must have arrived in Gotha. However, despite my efforts, I was not able to find Seetzen's catalogue or list there.

33 See especially volumes 3,1-3,5 (Die arabischen Handschriften).

34 See the database for manuscript notes for the Gotha collection available under the URL http://www.manuscripts-gotha.uni-jena.de/content/index.xml?lang=en. In the framework of the project "Stories of Survival: Recovering the Connected Histories of Eastern Christianity in the Early Modern World" at Oxford University, a searchable database of all writings by Eastern Christians from 1500 to $175^{\circ}$ is currently created, which will also include secondary remarks in manuscripts.

35 See Francisco del Río Sánchez, Catalogue des manuscrits de la Fondation Georges et Mathilde Salem (Alep, Syrie) (Wiesbaden: Reichert, 2008), 34-35, for the catalogue entry on Salem Ar. 56 [Sbath 836].

36 URL: https://www.vhmml.org/readingRoom/. On the latest developments in the HMML 
What can we learn from the ownership statements by Ḥannā and his family members? On one level, such ownership statements help clarify family relations. We know from Seetzen that the physician had several sons and daughters with his second wife. ${ }^{37}$ Seetzen does not give us their names. In the ownership statements, the names of Anțūn, Shukrī (Shukr Allāh), Ilyās, Jibrāāl and Rufāīl appear but otherwise we know next to nothing about them. The latter seems to have died in 1762 from the plague, ${ }^{38}$ more than a decade before Ḥannā's death. The ownership statements also provide evidence that one of Hannā's sons was a physician, like his father. Ḥannā bequeathed virtually all his medical works to Shukrī (Shukr Allāh). This son is also explicitly identified in the books as a "physician" (tabīb). ${ }^{39}$

Two further family members appear frequently in ownership statements: Ḥannā's father, Shukrī Ārūtīn al-Ṭabīb, and Anțūn Ārūtīn (al-Kabīr), either a brother of Ḥannā's father, or another brother of Ḥannā himself-besides Arsāniyūs.

Hannā's ownership statements frequently appear in the form "it entered the possession of the lowly shammās Hannā Shukrī Tabīb the Maronite" (dakhala bi-milk al-haquìr shammās Hannā Shukrī Ṭabīb Mārūnī) (see fig. 1), or, alternatively, "it entered the possession of the lowly shammās Hannā b. Shukrī Tabīb the Maronite" (qad dakhala bi-milk al-haqïr shammās Hannā b. Shukrì Ṭabīb alMārūnī). It is not rare that devotional formula such as haqīr or faqìr are left out altogether. In a few cases, ownership statements are much more complex (see fig. 2 and fig. 3). ${ }^{40}$ The terminus shammās does not imply that Hannā was part of the church hierarchy, but it was frequently used among Christians to indicate their pious devotion to the church.

Extremely rare is the form Yūḥannā: Ḥannā's son Ilyās, who inherited a number of manuscripts, called himself once al-faqïr Ilyās walad al-marhüm al-shammās Yūhannā Shukrī Tabīb al-Mārūnī. ${ }^{41}$ Otherwise Ilyās used the form

digitization project, see Columba Stewart, "An Update on the Digitization and Cataloging Work of the Hill Museum and Manuscript Library (HмML)," Christian Orient 8 (2017):153170. I refer to manuscripts from the Bibliothèque Orientale below with the abbreviation во usJ, generally used.

37 See Seetzen, "Nachrichten," 109.

38 See Aghnātiyūs Dīk, al-Huḍūr al-masīhì fì Halab khilāl al-alfayn al-munșarimayn, part 2, vol. 1: al-'Ahd al-'uthmānī al-awwal (Aleppo: Mațba'at al-Iḥsān, 2003), 248.

39 See for example Gotha, Ms. Orient. T 122, $1^{\mathrm{a}}$.

40 On the formulaic inventory of ownership statements, see Adam Gacek, "Ownership Statements and Seals in Arabic Manuscripts," Manuscripts of the Middle East 2 (1987): 88-95 (in systematic and diachronic perspective). See also the remarks in Liebrenz, Die Rifä $\bar{c} y a$, especially $23-26$.

Gotha, Ms. Orient. A $2654,77^{\text {b }}$. 


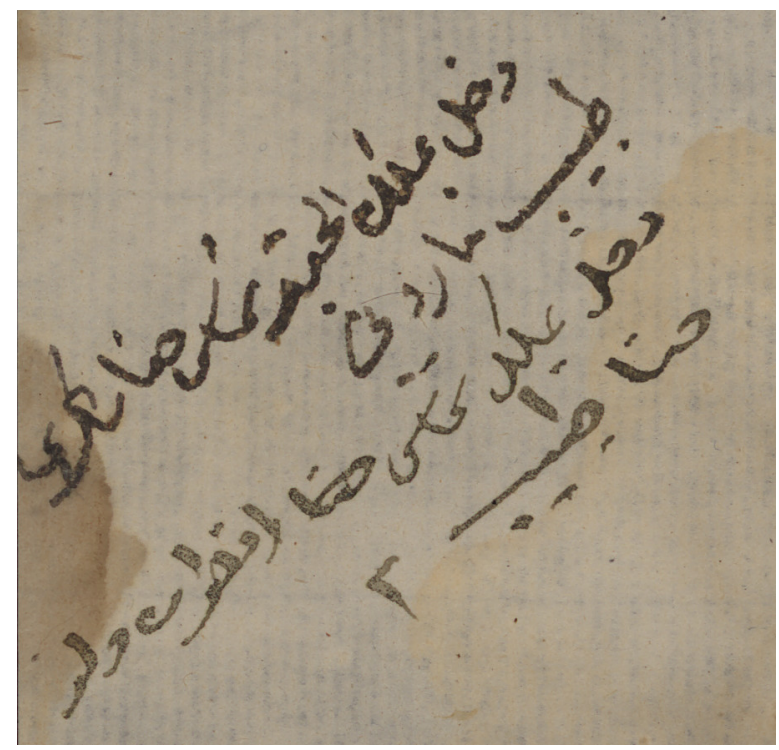

FIGURE 1 Ownership statements by Hannā al-Tabīb and his son Anțūn (below), starting with the frequently employed formula "it entered the possession" (dakhala bi-milk). Ms. Gotha Orient. T 118, fol. $63^{\mathrm{a}}$

walad Hannā. Rufầīl — the son who died early—used the form Yūḥannā in a Karshūnī manuscript, calling himself al-haqür bayna l-kahana al-quss Rufǟil walad Yühannā Tabīb. ${ }^{42}$ These two exceptions suggest that the Yūhannā mentioned in the stamp in Gotha, Ms. Orient. A 1933 is Ḥannā al-Ṭabīb.43 (See fig. 4.) Although the physician never used the form Yūhannā for himself, this is very probable because Hannā's father owned the book. Besides a statement by a Christian owner of the book dated to $1006 \mathrm{AH}(=1597-1598),{ }^{44}$ Shukrī al-Tabīb identified himself as an owner in $1112 \mathrm{AH}(=1700-1701) .45$

As for the sons' ownership statements, they were often added below Ḥannā's. While the practice of crossing out the names of previous owners was common, ${ }^{46}$ the sons did not cross out their father's name, but rather complemented his statements with their own. When the books were sold, neither the sons', nor

\footnotetext{
42 Gotha, Ms. Orient. A 286o, $1^{\mathrm{a}}$.

43 The seal is not easy to decipher: al-faqīr Yühannā al-Ṭabīb. It appears three times in the same manuscript, twice on folio $3^{\mathrm{a}}$ and once in $172^{\mathrm{a}}$, where it is clearer.

44 Gotha, Ms. Orient. A 1933, 181 ${ }^{\mathrm{a}}$.

45 Gotha, Ms. Orient. A $1933,1^{\mathrm{a}}$.

46 For this practice, see the remarks in Liebrenz, Die Rifāì̄ya, 22-23.
} 


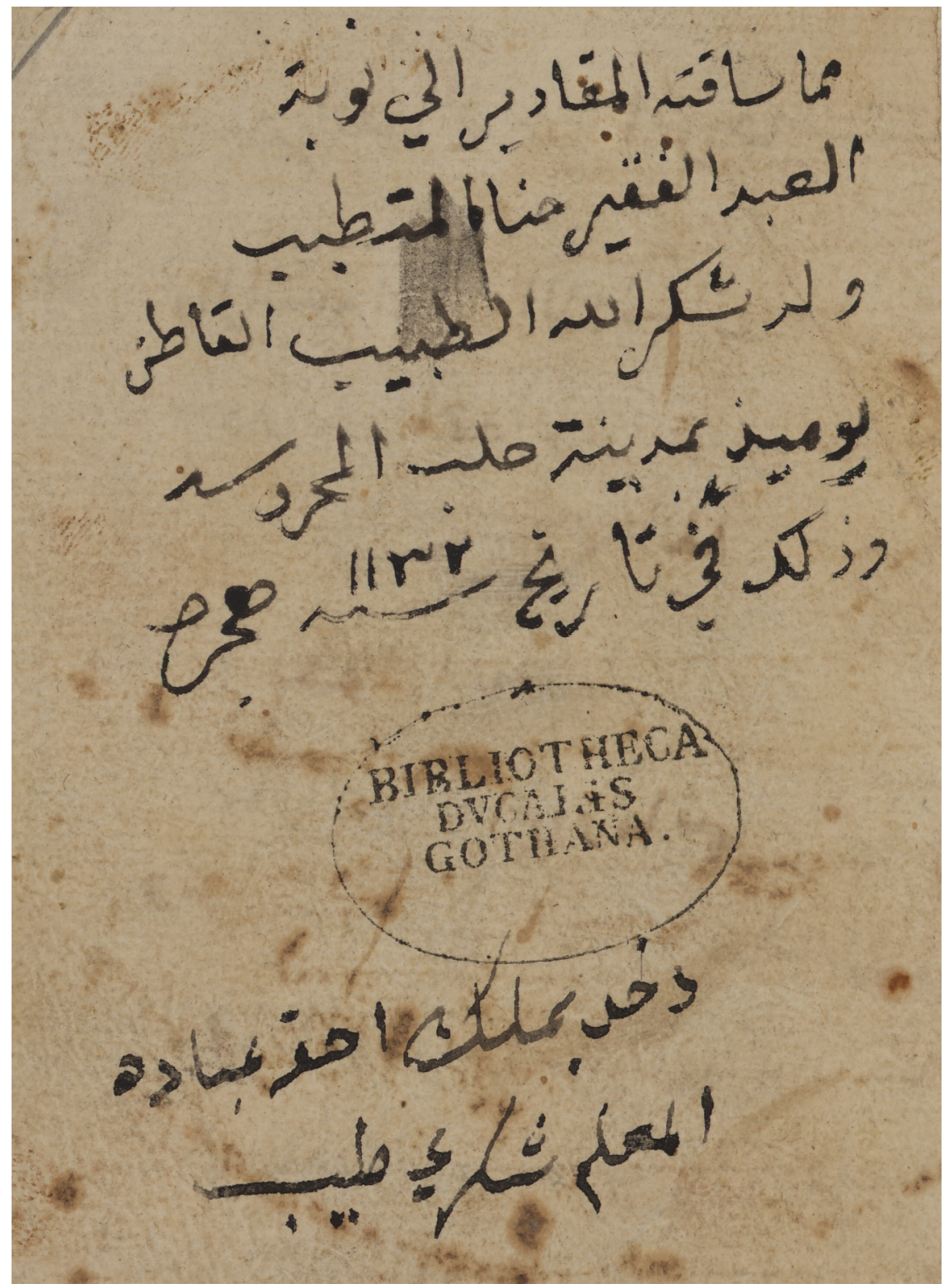

FIGURE 2 Complex ownership statement by Hannā al-Ṭabīb, dated to 1132 AH (1720 AD). The book, which deals with mineralogy, must have been acquired by the physician when he was about eighteen years old. Below follows an ownership statement by his son Shukrī, who also was a physician. Ms. Gotha Orient. A 2111, fol. $\mathrm{r}^{\mathrm{a}}$ 


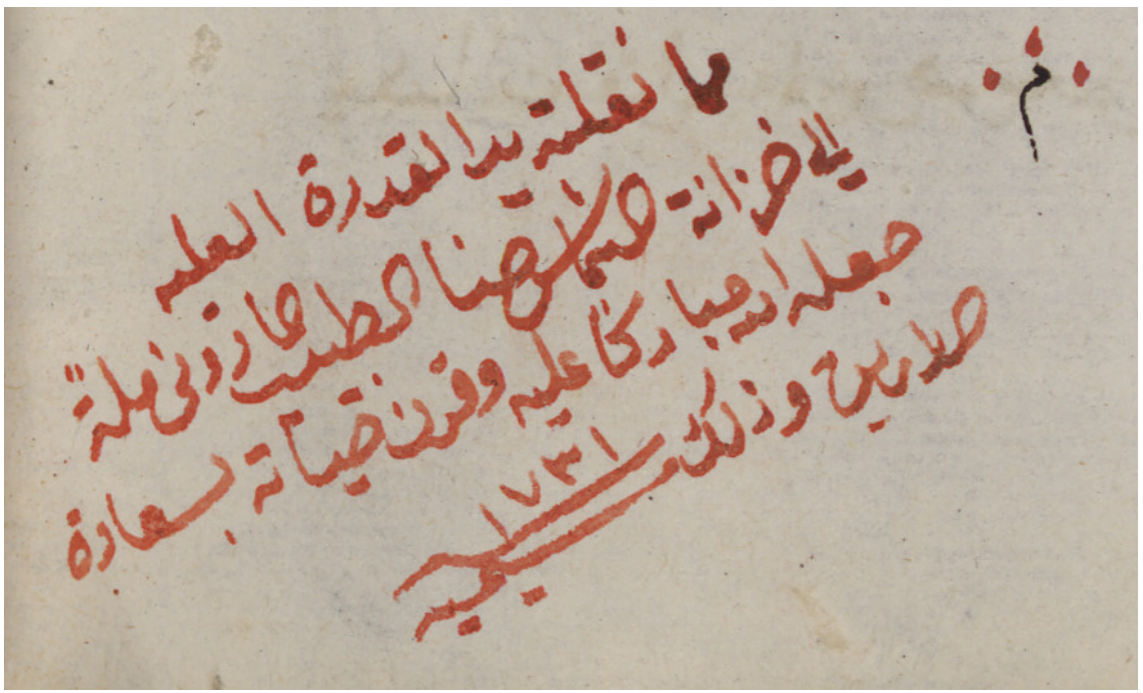

FIGURE 3 Complex ownership statement by Hannā al-Ṭabīb, dated to 1731AD. Ms. Gotha Orient. A 1207, fol. $122^{\text {b }}$

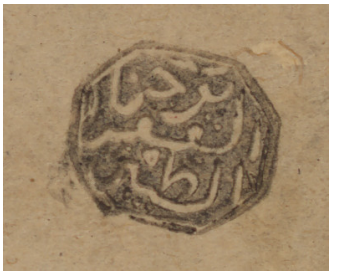

\section{FIGURE 4}

A stamp according to which the book was owned by "the poor Yūḥannā al-Ṭabīb", who can be identified as Hannā al-Ṭabīb. Another ownership statement shows that the manuscript belonged to his father and Hannā is called Yūḥannā elsewhere in Karshuni ownership statements. Ms. Gotha Orient. A 1933, fol. $172^{\mathrm{a}}$

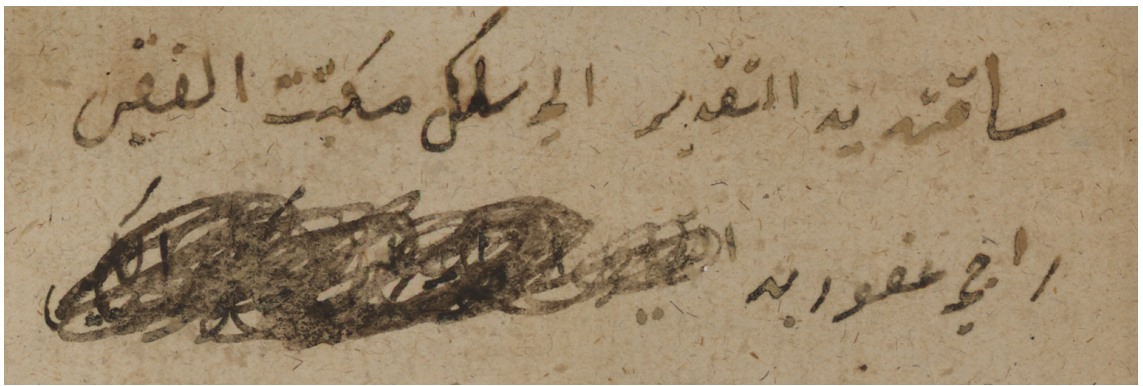

FIGURE 5 Erasure of the name Anțūn b. Shukrī al-Ṭabīb al-Kabīr in an ownership statement. The name can be reconstructed based on parallel statements and erasures in other manuscripts. Ms. Gotha Orient. A 2154, fol. $181^{\text {b }}$ 
Ḥannā's names were erased by the family. Evidently, the sons took pride in following in Hannā's footsteps; the way they added their names to their father's suggests a certain awareness of continuity. While following the form of his father's ownership statement closely, Anțūn accidentally started to write his father's name in fig. 1, instead of his own, and had to cross it out. The cancellation is barely visible. In contrast, other previous owners from the family were crossed out without further ado, for example in one case in which the manuscript probably belonged to Hannā's brother (or his uncle) - a certain Anțūn al-Kabīr. His name was erased here and there (see fig. 5).

To this date, I have identified $5^{2}$ manuscripts ( 47 works, some of them multivolume) that belonged to Hannā al-Ṭabīb. The number of manuscripts in which Ḥannā himself is mentioned as the owner amounts to $42 .{ }^{47} \mathrm{In}$ ten cases, books belonged to his father and his sons, so it is reasonable to assume that they belonged to Ḥannā himself, too, before the sons inherited them. In 26 further manuscripts, only one of the sons is mentioned as the owner (Anțūn in 15, Shukrī (Shukr Allāh) in 7, Ilyās in 3, Jibrāīl and Rufāìl together in 1). While the sons owned numerous manuscripts that had previously belonged to their father, we cannot be certain in these 26 cases, in which Ḥannā's name does not appear. They might have been new acquisitions and therefore must be excluded from an analysis of Ḥannā’s library.

The works in Ḥannā's library belong to a vast number of different fields of knowledge. Liebrenz has already discussed the problems involved in assigning works to categories in the framework of a thematic analysis of a library. ${ }^{48}$ This discussion need not be repeated here. However, it is important to note that early modern categories do not correspond to modern library categories and therefore need to be chosen with caution and problematized in order for them to be meaningful tools for the analysis of the thematic spectrum of a library.

Almost half of the works Ḥannā al-Ṭabīb owned were books relating to medicine or the natural sciences, which points to a specialized collection.

\footnotetext{
47 Two of these manuscripts do not contain ownership statements to this effect, but they can still be easily identified as Ḥannā's: his own travelogue (Gotha, Ms. Orient. A 1550) and his brother's travelogue (во, USJ 1764), which was written by Ḥannā’s hand.

48 See Liebrenz, Die Rifāìya, 8o-84.
} 

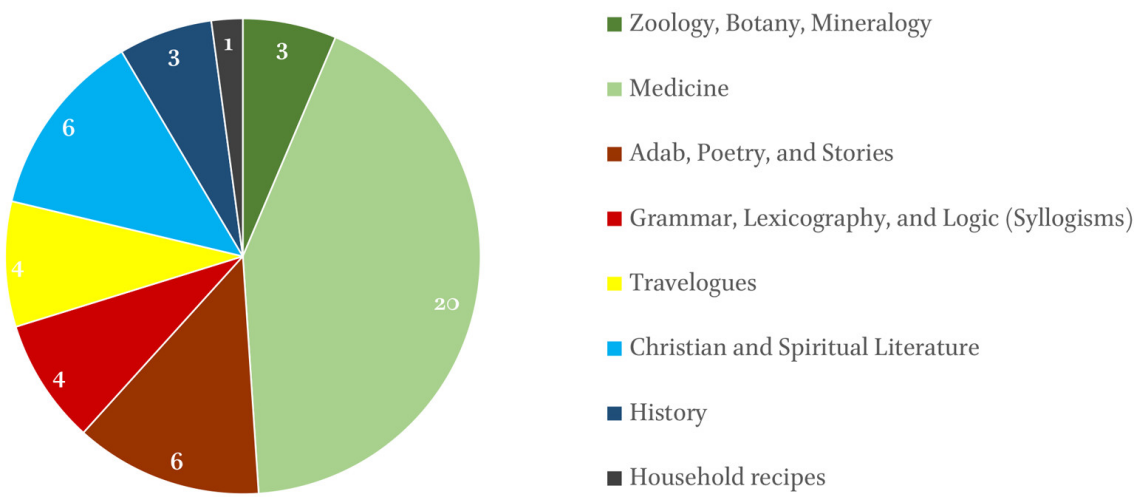

FIGURE 6 The different fields of knowledge represented in Ḥannā al-Ṭabīb’s book collection. The numbers indicate the number of works, not manuscripts (works consisting of several volumes factor into the diagram once)

Discussing the medical profession in Aleppo, the Russell brothers make the following observation on the use of medical books:

The books most read are modern abridgements of ancient authors, or collections made from various writers [...]. A book of this kind descends by inheritance in the family, and being sometimes enriched with choice recipies $[s i c]$, or secrets, it is carefully preserved till the failure of male heirs brings it into publick $[$ sic $]$ circulation. ${ }^{49}$

Hannā's library certainly validates these statements: the medical books in his library, many of them ancient authors, were passed down from generation to generation. The library betrays an orientation towards Galenic humoral pathology: The physician owned the commentary on Ibn Sīnā's Qānūn by Ibn alNafìs (d. 678/1288), entitled Müjaz al-Qānūn fì l-țibb, ${ }^{50}$ and even a commentary on the commentary by Sadīd al-Dīn al-Kāzarūnī. ${ }^{51}$ Besides other works firmly rooted in Galenism, such as the Kitāb al-a'däa al-älima li-Jāliyanūs, ${ }^{52}$ the physician also owned a newer medical, iatrochemical work like the Kitäb al-

49 Russell/ Russell, Natural History ${ }^{2}$, vol. 2, 121.

50 Gotha, Ms. Orient. A 1921. Doubts regarding Ibn al-Nafis's authorship have been articulated by Nahyan Fancy, "Medical Commentaries: A Preliminary Examination of Ibn al-Nafis's Shurūh, the Mūjaz and Subsequent Commentaries on the Mūjaz," Oriens 41 (2013): 525545. I thank Boris Liebrenz for this reference.

$5^{1}$ Gotha, Ms. Orient. A 1925.

52 Gotha, Ms. Orient. A 1901. 
țibb al-jadīd al-kimiyā̄ì lladhì khtara'ahū Barāklisūs. ${ }^{53}$ Interestingly, even "medical adab" is represented in the collection, notably Ibn Buṭan's widely known $D a^{\prime}$ wat al-atibba $\bar{a}^{3}$, a semi-autobiographical text usually attributed to the genre of the maqāma, containing also epic and dramatic elements. It narrates the journey of a young man, who, having left his home Baghdad in order to advance his career, has to struggle with incompetent physicians. ${ }^{54}$

Despite the huge proportional share of books on medicine, Hannā's book collection has a broad thematic range and also reflects a keen interest in literature and Arabic. Grammatical and lexicographical works are represented in Ḥannā's library. He owned, for example, Ibn al-Hājib's al-Käfyy fíl-naḥ̂, a classical work on Arabic grammar. ${ }^{55}$ If anything, the diagram underrepresents this part of the library, as one of the works, the Täjal-lugha wa-siḥạh al-'arabiyya by al-Jawharī, actually comprises four volumes. ${ }^{56}$

The interest in Arabic, its grammar and lexicography, resonates with the energetic devotion to the Arabic language that characterized what Hilary Kilpatrick has called a "literary renaissance" among Christians-a phenomenon that emerged from networks of priests and scholars spanning Mount Lebanon and Aleppo. ${ }^{57}$ It received a strong impulse from the Arabization of liturgy, itself a response to the missionary activities described in the introduction to this contribution. It was characterized both by a return to classical Arabic literature, but also by an engagement with the simplification and diffusion of knowledge on grammar and lexicography. 58

The presence of classical works on Arabic grammar and lexicography in Hannā's library suggests the great impact of the literary movement on different strata of society; it was not an elite project by churchmen, but a collective endeavor. Foremost among Aleppo's erudite litterateurs were Jirmānūs Jibrā̄̄l Farḥāt (1670-1732), Mikirdīj (Mkrtič) al-Kasīḥ (born 1666) and Niqūlā al-Șāiigh (1692-1756) who are frequently said to have been pioneering the literary movement. Hannā was very probably acquainted with at least two of these pioneers. Since 1725, Jirmānūs Farḥāt was bishop of Ḥannā’s community; Ḥannā would have had ample occasion to meet him as a young man. Additionally, among

\footnotetext{
53 Gotha, Ms. Orient. A 1941.

54 Gotha, Ms. Orient. A 19o9.

55 Gotha, Ms. Orient. A 250.

56 Gotha, Mss. Orient. A 384, A 386, A 39o, and A 392.

57 See Hilary Kilpatrick, "From Literatur to Adab:The Literary Renaissance in Aleppo Around 1700," Journal of Eastern Christian Studies 58 (2006): 195-220.

58 See the comments on liturgy and the process of Arabization in Abdulrazzak Patel, The Arab Nahdiah: The Making of the Intellectual and Humanist Movement (Edinburgh: Edinburgh University Press, 2013), 39.
} 
the books owned by Ḥannā's sons, we encounter Farḥāt's al-Ajwiba al-jalīya fì l-uṣūl al-naḩwiyya. ${ }^{59}$ Another manuscript that belonged to Ḥannā himself, the above mentioned Kitāb al-țibb al-jadìd al-kimiyā’ $\bar{\imath}$ was copied by Mikirdīj al-Kasīh according to its colophon. ${ }^{60}$ Several of Ḥannā's sons also owned alKasīḥ’s Rayhāanāt al-arwāh wa-sullam al-adab wa-l-șalāh, a collection of ascetic sayings. ${ }^{61}$

Against this background, it is particularly interesting to note the non-negligible number of travelogues in the library, many of them written in Middle Arabic by contemporaries from the physician's immediate environment. Besides his own account of his journey to Istanbul, Hannā owned three further manuscripts with travelogues.

The first travelogue is a translation into Arabic of the Sefaretname authored by the Ottoman diplomat Yirmisekiz Mehmed Çelebi Efendi (d. 1732). ${ }^{62}$ The latter was sent to Paris on a diplomatic mission in 1720-1721. Once he returned, he wrote a report for Ahmed III (r. 1703-1730). The French ambassador, who received copies, made Julien-Claude Galland (a nephew of Antoine Galland) translate the text into French. ${ }^{63}$ Interestingly, at the exact time when Galland produced his translation, another French translation was prepared in Aleppo, by a French dragoman named Joseph Aubert. ${ }^{64}$ Arabic translations of the Sefaretname were copied surprisingly often in Aleppo-a number of such copies belonged to Christian families. ${ }^{65}$

The other two copies both contain the travelogue of Hannā's brother Arsāniyūs. ${ }^{66}$ The latter travelled to Europe (France, Spain, Portugal, and Italy) in

59 Gotha, Ms. Orient. A 313.

6o Gotha, Ms. Orient. A 1941.

61 For this book of sayings, see the comments by Kilpatrick, "The Literary Renaissance," 210212.

62 Gotha, Ms. Orient. 1548.

63 See Gilles Veinstein, "Introduction," in Mehmed efendi: Le Paradis des infidèles: Relation de Yirmisekiz Çelebi Mehmed efendi, ambassadeur ottoman en France sous la Régence, translated by J.-C. Galland (Paris: Maspero, 1981), 7-51, 39-40.

64 See Veinstein, "Introduction," 40.

65 Vatican, Sbath 108, which contains a Sefaretname translation, for example, was likely copied by the Maronite Hannā Diyāb, an acquaintance of Hannā al-Ṭabīb and author of a travelogue as well. (On Ḥannā Diyāb, see the remarks further below.) John-Paul Ghobrial suggested convincingly that Ḥannā Diyāb copied Sbath 108, see John-Paul Ghobrial, "Stories Never Told: The First Arabic History of the New World," Osmanlı Araştırmaları/ The Journal of Ottoman Studies 40 (2012): 259-282, 263-264, especially fn. 8.

66 Gotha, Ms. Orient. A 1549 and во, USJ 1764. On the travelogue and the journey, see Seetzen, "Nachrichten," 106-109; see also Georg Graf, Geschichte der christlichen arabischen Literatur. Vol. 3, Die Schriftsteller von der Mitte des 15. bis zum Ende des 19. Jahrhunderts: 
order to collect alms for his indebted order from the Catholic courts of Europe. Like Ḥannā, he wrote down his observations on a range of topics-technical inventions, episodes of unrest in Paris, religious processions, and courtly protocol, just to name a few. Interestingly, the account was written down by Ḥannā himself, as not only the handwriting suggests, but as the colophon clearly states:

The most humble servant, the poor Hiannā, also called shammās and physician, the son of Shukrī, brother of Father Arsāniyūs, who ventured on this journey and is nowadays Bishop of the Maronites in the city of Aleppo, wrote or rather copied (katabahū bal sawwadahū) [this travelogue]. May God grant him a long life, continue to guide us spiritually and make obedience easy on us. This [was written] in the year 1764, on the thirtieth day of the month of May. ${ }^{67}$

Accounts of travels from Ḥannā's immediate milieu represent a significant part of the physician's library. It is, therefore, safe to attest to individuals from his immediate milieu a strong self-involvement in the literary field.

The books in the library that cover adab, poetry, or stories, reflect both an interest in higher learning and light "amusement" literature. Șafì al-Dīn alHillī (d. 739/ 1339), for example, was a famous Arab poet from the Mamluk era; his divan, which Ḥannā al-Ṭabīb owned, ${ }^{68}$ is written in fuṣhāa and covers the full range of classical forms (khamriyyāt, țardiyyāt, madh, hijä etc.). This example points to an interest in the classical canon of Arabic poetry. By contrast, Ibn Sūdūn's (d. 868/1464) Kitāb Nuzhat al-nufüs wa-muḍhik al-'abūs, is an $a d a b$ work containing both prose and rhyme, with a thematic spectrum ranging from praise of the Prophet to almost obscene and sexually explicit poems. Non-classical verses in this collection abound with colloquialisms. While some scholars therefore have dubbed this work "popular", Arnoud Vrolijk claims that Ibn Sūdūn rather aimed at informality instead of a certain stratum of society. Still, the work stands for a partaking of the educated elites in popular culture for purposes of entertainment. The deliberately introduced vernacular elements made this work popular both with elites and the common people. ${ }^{69}$

Melchiten, Maroniten (Vatican City: Biblioteca Apostolica Vaticana, 1949), 466, and Joseph Nasrallah, Histoire du mouvement littéraire dans l'Église melchite du $v^{e}$ au XX $X^{e}$ siècle. Vol. 4, Époque ottomane. 1516-1900, Part 2, 1724-180o. (Leuven: Peeters, 1989), 301.

67 Gotha, Ms. Orient. A 1549, $215^{\mathrm{r}}$.

68 Gotha, Ms. Orient. A 2300.

69 Gotha, Ms. Orient. A 2159. See the study and edition by Arnoud Vrolijk, Bringing a Laugh to 
Another significant section of Ḥannā's library covers spiritual literature. It is interesting to note the absence of a psalter or bible. One would expect them to be a vital addition to a library containing religious literature. Instead, Ḥannā owned polemical treatises such as the widely diffused Mujādalat al-rāhib alsam 'ān $\bar{\imath},{ }^{70}$ ascetical works, and spiritual guidebooks. Heyberger has underlined the importance of these works of devotion for a change in Christian sensibilities, for newly emerging modes of reading that touched upon individual conscience. ${ }^{71}$ For a book owner who became an author himself, the presence of such books is certainly remarkable. After all, the introspective "I" characterizing this kind of literature, is not so far removed from the "I" of the traveller who narrates his own subjective feelings and impressions.

An oddity in the library is certainly a book on spot-removal owned by Ḥannā. Luṭfallāh Qārī has examined a number of such treatises in diachronic perspective, from the ninth to the seventeenth century. ${ }^{72}$ The removal of spots was relevant to the art and practices of writing, not only household work-perhaps it can therefore be related to the physician's writing activities.

To sum up, while Hannā's library certainly reflects a specialized interest in medicine, the thematic spectrum of the library is much broader and displays a keen interest in the Arabic language and its literary heritage. But the library is variegated where languages are concerned as well. Hannā owned a Syriac lexicographical work, ${ }^{73}$ but also a medical treatise written in Ottoman Turkish. ${ }^{74}$ Many of the manuscripts' previous owners were indeed Muslims and some manuscripts were old, such as Ms. Orient. A 392, which was copied in 617 AH/ 1221 in Tikrit and, in the beginning of the seventeenth century, belonged to a member of Aleppo's a'yān, from the 'Urḍi family. At present, we are unable to say if the library was also variegated in that it contained prints alongside manuscripts. It is possible that the library in Gotha preserves printed works that bear ownership statements by Hannā and his family. This opens up another promising avenue for future research.

a Scowling Face: A Study and Critical Edition of the "Nuzhat al-nufüs wa-mudhikal-'abūs" by 'Alì Ibn Sūdūn al-Bashbughāwì (Cairo 810/1407-Damascus 868/1464) (Leiden: Brill, 1998). See ibid., 39-47, on the reception of the Nuzha.

70 Gotha, Ms. Orient. A 2875 .

71 See Heyberger, "Livres," 221.

72 Gotha, Ms. Orient. A 1332. See Luṭfallāh Qārī [Lutfallah Gari], "Mu’allafāt qal' al-āthār fì l-turāth al-'arabī," Journal of Islamic Manuscripts 6 (2015): 132-196.

73 вO USJ 152 .

74 Gotha, Ms. Orient. T 118. 


\section{Christian Book Owners: Affluent Bibliophiles with a Taste for Enkyklios Paideia}

What did it mean for Ḥannā to own such a large library that reflected his wideranging interest? What did it mean for Christians in Hannā's immediate milieu to own books? In what follows, I will explore the significance of book ownership in eighteenth-century Aleppo, considering also comments and observations by contemporaries that help us come to grips with this aspect of Aleppo's intellectual culture.

A dispute among Maronite Christians over five books, which lasted more than a decade, sheds light on the monetary value of books in Ḥannā's milieu. ${ }^{75}$ A tailor named Ilyās b. Sam‘ān owed Zakkūr Ḥawshab money. The creditor died in $175^{2}$ without ever getting his money back, but five books (several Bibles and Acts of Apostles) belonging to the tailor were in his possession. Bishop Jibrāîl Hawshab, the creditor's brother, inherited the books with the rest of the estate. These books, however, did not become church property, but entered the private possessions of the bishop. Before Ilyās himself died in 1763, he tried—without success - to convince the bishop to give him the books back. However, even after the tailor's death, the dispute was not settled. When Jibrāil H. Hawshab died, too, his nephew, Ni'ma walad Ilyās Fathallāh, claimed the books from the new bishop Arsāniyūs, insisting that they were private property of his predecessor. The dispute illustrates that book ownership had taken root among different social strata, even tailors. Books were obviously of significant material value; so much so that they were worthwhile to be fought over.

As Seetzen observed during his stay in Constantinople, the price of a book was determined by its novelty, preservation, ornamentation, calligraphy, and its uncommonness. ${ }^{76}$ In Aleppo, he heard about a rare (supposedly complete) copy of Thousand and One Nights that was sold for the enormous price of 1.500 piasters. ${ }^{77}$

It is not insignificant that Hannā al-Ṭabīb was a physician, and thus a person of considerable financial means. It seems probable that he was able to afford such a huge number of books thanks to the financial resources stemming from

75 Archive of the Maronite Diocese in Aleppo, folder of Bishop Arsāniyūs, no. 55 .

76 See Ulrich Jasper Seetzen, Tagebuch des Aufenthalts in Konstantinopel und der Reise nach Aleppo 1802-1803, ed. V. Enderlein et al. (Hildesheim: Olms, 2012), 195. For a discussion of book prices, see Boris Liebrenz, "'Mit Gold nicht aufzuwiegen': Der Wert von Büchern im osmanischen Syrien (11.-13. / 17.-19. Jahrhundert)," Zeitschrift der Deutschen Morgenländischen Gesellschaft 164.3 (2014): 653-686, and id., Die Rifä‘ūya, 72-78.

See Seetzen, Tagebuch des Aufenthalts in Aleppo, 5 o. 
his work as a doctor. We know that the medical profession was extremely profitable among Christians, for example from monastic account books. Abū Nahrā has shown for the convent Dayr Mār Ash'ayyā' in Brummana (Lebanon) that a small number of monks who administered medical services earned sums equaling the gains for the entire agricultural production of the convent. The monk Procope, who was a renowned physician, earned 156.5 piasters in 1743 , 1398 piasters in $175^{1}$ and the mind-boggling sum of $325^{2}$ piasters in 1754 . In comparison, the average worker earned 0.23 piasters per day, which amounted to 69 piasters per year (if he worked for 300 days). ${ }^{78}$ Nasrallah, too, in his discussion of Melkite Christian physicians and their literary output, mentions their high gains repeatedly. ${ }^{79}$

However, the value of books was not only a monetary issue. The materiality of books also inspired awe. They were admired for their beauty, ornateness, and rarity. Ḥannā al-Ṭabīb's brother Arsāniyūs was smitten with the libraries he visited in France and in Spain. He makes the following observations on manuscripts he saw in Spain and compares them to the books owned by his congregation:

They made us climb the stairs to a second library, where the hand-written books are preserved. There are two thousand one hundred hand-written books in Arabic and they are extremely precious books. Among them, there is a Koran, which is written in golden ink. There are other unique and rare books about history, medicine, astronomy, mathematics, and many other sciences. [...] When we saw these riches and these glorious things, we became more aware of our poverty. Our misery, our bad situation, and the poverty of our order became apparent to us. We thought of our glorious and rich library in which there are two liturgical books, two psalters-one of them [copied by Jibrāìl] al-Ṣahyūnì and the other printed — and an old gospel. ${ }^{80}$

While books were clearly seen as valuable and prestigious possessions, they were simultaneously tokens for intellectual dynamism. Their accumulation in great variety (mostly on the level of themes) goes hand in hand with a growing appetite for books in different strata of society and an increasingly active

${ }_{78}$ See Yūsīf Abū Nahrā, al-Iklīrūs wa-l-milkiyya wa-l-sulța. Abḥāth fì tārīkh Lubnān al-ijtimā̄o wa-l-iqtiṣādī (Beirut: Dār al-Nahār, 2007), 86.

79 See for example Nasrallah, Mouvement, 286 (for Benedict Turkmānī), and 289 (on Procope).

8o Gotha, Ms. Orient. A 1549, $168^{\mathrm{a}}$. 
engagement in the literary field. This interest was potentially expansive and less parochial. The possession of a selection of books from the classical canon of confession or profession did not satisfy book owners' appetites. With regard to the (mostly Muslim) book owners of Damascus, Establet and Pascual have observed a similar trend of "anti-specialisation" and the emergence of an "encyclopedic culture" in Damascus. ${ }^{81}$ Even the library of a Christian monastery, such as al-Shuwayr in Mount Lebanon, offered a broad spectrum of literature, including philosophy, natural sciences, Islamic religious works, belles-lettres, historiography, medicine, and philology, as Carsten Walbiner has shown. ${ }^{82}$ If more evidence to this effect can be found, such a taste for enkyklios paideia, a "general education", would certainly not be independent of similar developments in eighteenth century Europe.

Seetzen provides additional evidence in his diary that libraries were reshaped in view of their Western counter-parts. In an entry dated to December 29, 1804, he compares the "ancient Greek" (i.e. Orthodox) library with the library of the Maronites in Aleppo:

Today, I visited the ancient Greek Bishop, accompanied by my friends Vaughon and Sebastiani [...]. They led us to a small, dark room with a dome, which appeared more like a prison than anything else. Although it was daytime, they had to light a lamp, so that we could see the books. This visit was not worth the trouble. We found only 100 volumes, maximum, almost all of them related to worship or ecclesiastical works. They were in part works printed in Europe and in part Arabic manuscripts. We noticed Chrysostom's works in Arabic, Aristotle's works, printed in Basle etc. Among the ancient Greek priests, one encounters little erudition, because they do not yet have good institutions of learning. Among the Uniate Greeks, one encounters more knowledge, because many of their priests studied in Rome. The same can be said about the Uniate Armenians and the Maronites.

We had more success with the Bishop of the Maronites, whom we visited afterwards. [...] After a reception with the usual hospitality, the Bishop led us to the library, which is not big, but light and airy. There, the

81 See Colette Establet and Jean-Paul Pascual, "Les livres des gens à Damas vers 1700," Revue des Mondes Musulmans et de la Méditerranée 87-88 (1999): 143-175, 156: "antispécialisation"; "une culture encyclopédique".

82 Carsten Walbiner, "Monastic Reading and Learning in Eighteenth-Century Bilād al-Šām: Some Evidence from the Monastery of al-Šuwayr (Mount Lebanon)," Arabica 51.4 (2004): 462-477. 
books were arranged following European style. According to the information provided by the warden, there are 6oo manuscripts in Arabic, 200 in Syriac or Karshuni, and 200 printed books, in part from Lebanon, in part from Europe, altogether 1000 volumes. These books do not only comprise ecclesiastical books and prayers; instead, they cover all scientific disciplines. For example, poems, stories, medical and historical works, grammatical treatises, etc. can be found. Four of the church clerks have the task to see to the library's orderliness, to revise the catalogue, to write down which books were borrowed and to call them back, etc. ${ }^{83}$

Seetzen describes the state of the Maronite library after Arsāniyūs' tenure of office. The library he visited contrasted strongly with the Greek Orthodox library, both in view of its relative vastness and diversity. Besides pious literature, the library offered a broad thematic spectrum of works, "poems, stories, medical and historical works, grammatical treatises." The same spectrum is displayed by Ḥannā al-Ṭabīb's collection of books. In addition, the references to the library's "European style" organization and to the European prints point to the importance of global horizons in the culture of the book.

Owning books was an integral part of literary agency and bespoke a commitment to literary activities. In Ḥannā's milieu, owning books, copying them, or authoring them, were related activities: Bishop Farhạat, who was one of the great litterateurs of the epoch, made significant donations to the Maronite library in Aleppo. The prolific Mikirdij al-Kasīh, to mention a second example, copied an iatrochemical work in Hiannā's collection.

It is significant in this respect that Ḥannā authored his own travelogue. While it is not known if he wrote anything else, he certainly became active as a copyist. He wrote down and copied the travelogue of his brother Arsāniyūs, as we learn from the colophons of two manuscripts that he owned. ${ }^{84}$ In this context, another travelogue in Middle Arabic needs to be mentioned, even though Ḥannā did not own a copy: It narrates the Maronite Christian Ḥannā Diyāb's travels through Tunisia, Spain, France, Italy and the Ottoman Empire. ${ }^{85}$ Inter-

\footnotetext{
83 See Seetzen, Tagebuch des Aufenthalts in Aleppo, 277-278 (translation mine).

84 Ms. Orient. A 1549 and во, USJ 1764. Ḥannā might have copied other works as well, in which no mention of the copyist is made. However, speculations based on hand-writing will not be followed here.

85 See Vatican, Sbath 254 (the beginning of the travelogue is missing); a translation of the entire text into French is available, see Hanna Dyâb, D'Alep à Paris: Les pérégrinations d'un jeune Syrien au temps de Louis XIV, translated by P. Fahmé-Thiéry, B. Heyberger and J. Lentin (Paris: Sindbad/actes sud 2015).
} 
estingly, it was completed in $1764,{ }^{86}$ many decades after the journey itself and in the same year in which Hannā al-Ṭabīb set out for his journey. Perhaps the travelogue came into being because Ḥannā al-Ṭabīb prompted his contemporary to write it down? While we will probably never know for sure, the case of Ḥannā al-Tabīb points to an enthusiastic engagement with literature. Owning books and staking a literary claim went hand in hand for the physician. of the Library Phenomenon

How can we make sense of the existence of a library such as Hannā's in eighteenth-century Aleppo? While the Christian milieu in which the library came into existence is certainly important, wider-imperial, regional, and local-conditions in the Ottoman Empire and its provinces should not be disregarded.

As for the imperial frame, we know that the eighteenth century saw the creation of a number of libraries throughout the Ottoman Empire. Powerful bureaucrats in particular founded public libraries as religious endowments, mostly in the capital, but also in the province. Ninety-eight libraries were founded between 1700 and 1799, 57 in Istanbul and its environment, the rest in the province. ${ }^{87}$

The existence of a library such as Hannā's is tied to regional developments as well. Nelly Hanna's research on book ownership in eighteenth-century Cairo has shed light on the expansion of the cultural sphere of an aspiring middle class which, thanks to an unprecedented material comfort, participated more actively in cultural production, and, above all, "could spend more money on nonessentials like books." ${ }^{88}$ Between 1730 and 1740, 19 o private libraries appear in probate records. ${ }^{89}$ Hanna argues that this development was connected to a new economic prosperity. A similar development can be observed in other regional contexts, even closer to Aleppo. Based on probate records covering the period between 1686 and 1717, for example, Establet and Pascual have traced a

\footnotetext{
86 Vatican, Sbath 254, 174 ${ }^{\mathrm{r}}$ (transl. Hanna Dyâb, D'Alep à Paris, 440).

87 See Henning Sievert, Zwischen arabischer Provinz und Hoher Pforte: Beziehungen, Bildung und Politik des osmanischen Bürokraten Rāğıb Meḥmed Paşa (st. 1763) (Würzburg: Ergon, 2008), 406.

88 Nelly Hanna, In Praise of Books: A Cultural History of Cairo's Middle Class, Sixteenth to Eighteenth Century. (Syracuse: Syracuse University Press, 2003), 48.

89 See Hanna, In Praise of Books, 85 .
} 
"well-defined milieu of the educated" in Damascus. ${ }^{90}$ They have observed that merchants and artisans figured prominently among the book owners. ${ }^{91}$ Book ownership was, to some degree, contingent upon income, and was a signifier of affluence in this period. ${ }^{92}$

Finally, Aleppo itself was a hub on the book market. Besides Ulrich Jasper Seetzen, who went to Aleppo to purchase books, the German bookseller Jonas Kortens, who travelled through Syria to the Holy Land (1737-1738), mentions that he was pleasantly surprised that he could buy printed books from Mount Lebanon in Aleppo, which meant that he could save the trip. ${ }^{93}$ Even Ottoman bureaucrats sent envoys to find and buy books for them in Aleppo. Notably Ragib Mehmed Paşa (d. 1763), a former governor of Aleppo and later Grand vizier in Istanbul, and above all the founder of an important public library in Istanbul, sent his kitabcı Salih to search for books in Aleppo in $1758 .{ }^{94}$

Hannā's library was not an isolated phenomenon. Instead, the physician's bibliophilism must be understood as an expression of a resurgence in literary activity in his milieu, and an enthusiasm for books among those who had the necessary resources, whose interests reverberated throughout the Empire and its provinces.

\section{Bibliography}

\section{Primary}

Manuscripts (and Archival Sources)

Aleppo, Archive of the Maronite Diocese, folder of Bishop Arsāniyūs, no. 55 .

Aleppo, Fondation Georges et Mathilde Salem, Salem Ar. 56 [Sbath 836].

Beirut, Bibliothèque Orientale, во USJ 1015, 1520, 1764 .

Gotha, Ms. Orient. A 35, A 250, A 384, A 386, A 39o, A 392, A 1207, A 1227, A 1332, A 1548, A 1549, A 1550, A 1580, A 1724, A 1841, A 1894, A 1895, A 1901, A 1909, A 1910, A 1921, A 1925, A 1932, A 1933, A 1941, A 1951, A 1965, A 1966, A 1979, A 1996, A 2001, A 20O2, A 2015, A 2026, A 2066, A 2111, A 2159, A 230O, A 2366, A 2379, A 2696, A 2770, A 2873, A 2874, A 2875,

\footnotetext{
$90 \quad$ See Establet and Pascual, "Les Livres," 149: "milieu bien défini de lettrés."

91 See Establet and Pascual, "Les Livres," 150-151.

92 See Establet and Pascual, "Les Livres," 153.

93 See Jonas Kortens, Jonas Kortens, ehemaligen Buchhändlers zu Altona, Reise nach dem weiland gelobten, nun aber seit siebzehn hundert Jahren unter dem Fluche liegenden Lande, wie auch nach Egypten, dem Berg Libanon, Syrien und Mesopotamien, von ihm selbst aufrichtig beschrieben (Halle: Joh. Christian Grunert, 1743), 414-415.

94 See Sievert, Zwischen arabischer Provinz, 424, fn. 189.
} 
T 118, T 122, T 176. [Further manuscripts belonging to Hannā's family quoted in the article: Ms. Orient. A 313, A 2154, A 2654, A 286o.]

Vatican, Bibliotheca Apostolica Vaticana, Sbath 254.

\section{Edited and Translated Sources}

Dyâb, Hanna, D'Alep à Paris: Les pérégrinations d'un jeune Syrien au temps de Louis XIV, translated by P. Fahmé-Thiéry, B. Heyberger and J. Lentin (Paris: Sindbad/actes sud, 2015).

Kortens, Jonas, Jonas Kortens, ehemaligen Buchhändlers zu Altona, Reise nach dem weiland gelobten, nun aber seit siebzehn hundert Jahren unter dem Fluche liegenden Lande, wie auch nach Egypten, dem Berg Libanon, Syrien und Mesopotamien, von ihm selbst aufrichtig beschrieben (Halle: Joh. Christian Grunert, 1743).

Russell, Alexander, revised, enlarged, and illustrated with notes by Patrick Russell, The Natural History of Aleppo: Containing a Description of the City, and the Principal Natural Productions in its Neighbourhood. Together with an Account of the Climate, Inhabitants, and Diseases, particularly of the Plague, 2 vols. (London: G.G. and J. Robinson, 1794 [Second edition]).

Schultz, Stephan, Der Leitungen des Höchsten nach seinem Rath auf den Reisen durch Europa, Asia und Africa, 5 vols. (Halle: Carl Hermann Hemmerde, 1771-1775).

Seetzen, Ulrich Jasper, “Doktor Seetzen's Reisenachrichten," Intelligenzblatt von Salzburg, 14 December 1805: 782-787.

Id., "Nachrichten von einigen Arabischen, Persischen und Türkischen Reisebeschreibungen, Topographien und andern geographischen Werken und Landkarten," Monatliche Correspondenz zur Beförderung der Erd-und Himmelskunde 12 (August 1805): 101-125.

Id., Tagebuch des Aufenthalts in Aleppo 1803-1805, ed. J. Zepter, C. Walbiner and M. Braune (Hildesheim: Olms, 2011).

Id., Tagebuch des Aufenthalts in Konstantinopel und der Reise nach Aleppo 1802-1803, ed. V. Enderlein et al. (Hildesheim: Olms, 2012).

\section{Literature}

Abū Nahrā, Yūsīf, al-Iklīrūs wa-l-milkiyya wa-l-sulța. Abḥāth fì tārīkh Lubnān al-ijtimāì wa-l-iqtiṣādī (Beirut: Dār al-Nahār, 2007).

Bacel, Paul, "Abdallah Zakher. Ses premiers travaux (168o-1722)," Échos d'Orient 11.71 (1908): 218-226.

Id., "Abdallah Zakher et son imprimerie arabe," Échos d'Orient 11.72 (1908): 281-287.

Id., "Dernières années d' Abdallah Zakher," Échos d'Orient 11.73 (1908): 363-372.

Braune, Michael, "Ulrich Jasper Seetzens Leben in der Community der Franken in Aleppo (1803-1805)," in Ulrich Jasper Seetzen (1767-1811): Jeveraner-aufgeklärter Unternehmer-wissenschaftlicher Orientreisender, ed. D. Haberland (Oldenburg: Isensee, 2014), 167-185. 
Cheikho, Louis, Kitāb al-Makhțūṭāt al-'arabiyya li-katabat al-nașrāniyya (Beirut: Imprimerie Catholique, 200o, reprint of the 1924 edition).

Dīk, Aghnātiyūs, al-Ḥựūr al-masị̣̂ fì Halab khilāl al-alfayn al-munșarimayn, part 2, vol. 1: al-'Ahd al-'uthmānī al-awwal (Aleppo: Maṭba'at al-Iḥsān, 2003).

Establet, Colette, and Jean-Paul Pascual, "Les livres des gens à Damas vers 1700," Revue des Mondes Musulmans et de la Méditerranée 87-88 (1999): 143-175.

Fancy, Nahyan, "Medical Commentaries: A Preliminary Examination of Ibn al-Nafîs's Shurūḥ, the Mūjaz and Subsequent Commentaries on the Mūjaz," Oriens 41 (2013): $525-545$.

Gacek, Adam, "Ownership Statements and Seals in Arabic Manuscripts," Manuscripts of the Middle East 2 (1987): 88-95.

Ghobrial, John-Paul, "The Ottoman World of 'Abdallah Zakher. Shuwayr Bindings in the Arcadian Library," in The Arcadian Library: Bindings and Provenance, ed. G. Mandelbrote and W. de Bruijn (London: Arcadian Library / Oxford University Press, 2014), 193-231.

Id., "Stories Never Told: The First Arabic History of the New World," Osmanlı Araștırmaları/The Journal of Ottoman Studies 40 (2012): 259-282.

Id., "The Archive of Orientalism and its Keepers: Re-Imagining the Histories of Arabic Manuscripts in Early Modern Europe," Past and Present (2016), Supplement 11: 90111.

Graf, Georg, Geschichte der christlichen arabischen Literatur. Vol. 3, Die Schriftstellervon der Mitte des 15. bis zum Ende des 19. Jahrhunderts: Melchiten, Maroniten (Vatican City: Biblioteca Apostolica Vaticana, 1949).

Haberland, Detlef, "Ulrich Jasper Seetzen-Ein Leben für eine Forschungsreise in den Vorderen Orient und auf die Arabische Halbinsel," in Ulrich Jasper Seetzen, Tagebuch des Aufenthalts in Aleppo 1803-1805 (Hildesheim: Olms, 2011), XIII-XL.

Hanna, Nelly, In Praise of Books: A Cultural History of Cairo's Middle Class, Sixteenth to Eighteenth Century. (Syracuse: Syracuse University Press, 2003).

Heyberger, Bernard, "Livres et pratique de la lecture chez les chrétiens (Syrie, Liban). XVII ${ }^{\mathrm{e}}-\mathrm{XVIII}{ }^{\mathrm{e}}$ siècles," Revue des Mondes Musulmans et de la Méditerranée 87-88 (1999): 209-223.

Hirschler, Konrad, Medieval Damascus: Plurality and Diversity in an Arabic Library: The Ashrafiya Library Catalogue (Edinburgh: Edinburgh University Press, 2016).

Kilpatrick, Hilary, "From Literatur to Adab: The Literary Renaissance in Aleppo Around 1700," Journal of Eastern Christian Studies $5^{8}$ (2006): 195-220.

Krimsti, Feras, Der Istanbul-Reisebericht des Aleppiner Arztes Hannā ț-Tabīb (1764/65): Alltagsbilder und identitäre Verortungen (PhD thesis Berlin, 2016).

Liebrenz, Boris, "Die Rifā̄̄ìya. Neue Forschungen zur Geschichte einer Familienbibliothek aus dem osmanischen Damaskus," in Das Buch in Antike, Mittelalter und Neuzeit: Sonderbestände der Universitätsbibliothek Leipzig, ed. Th. Fuchs, Ch. Mackert and R. Scholl (Wiesbaden: Harrassowitz, 2012), 265-277. 
Id., "The Library of Aḥmad al-Rabbāt: Books and their Audience in 12th to 13th/18th to 19th Century Syria," in Marginal Perspectives on Early Modern Ottoman Culture: Missionaries, Travellers, Booksellers, ed. U. Pietruschka and R. Elger (Halle: Zentrum für Interdisziplinäre Regionalstudien, Universität Halle, 2013), 17-59.

Id., “'Mit Gold nicht aufzuwiegen': Der Wert von Büchern im osmanischen Syrien (11.13./ 17.-19. Jahrhundert)," Zeitschrift der Deutschen Morgenländischen Gesellschaft 164.3 (2014): 653-686.

Id., Die Rifāìya aus Damaskus: Eine Privatbibliothek im osmanischen Syrien und ihr kulturelles Umfeld (Leiden: Brill, 2016).

Nasrallah, Joseph, Histoire du mouvement littéraire dans l'Église melchite du ve au $X X^{e}$ siècle. Vol. 4, Époque ottomane. 1516-19oo. Part 2, 1724-180o (Leuven: Peeters, 1989).

Patel, Abdulrazzak, The Arab Nahdiah: The Making of the Intellectual and Humanist Movement (Edinburgh: Edinburgh University Press, 2013).

Pertsch, Wilhelm, Die orientalischen Handschriften der Herzoglichen Bibliothek zu Gotha. Part 3: Die arabischen Handschriften, 5 vols. (Gotha: Perthes, 1878-1892).

Qārī, Luṭfallāh [Gari, Lutfallah], "Mu’allafāt qal' al-āthār fì l-turāth al-'arabī," Journal of Islamic Manuscripts 6 (2015): 132-196.

del Río Sánchez, Francisco, Catalogue des manuscrits de la Fondation Georges et Mathilde Salem (Alep, Syrie) (Wiesbaden: Reichert, 20o8).

Schmidt, Jan, "The Journey of Stephan Schultz, Protestant Missionary from Halle, in the Ottoman Empire 1752-1756," Oriens 39 (2011): 17-57.

Sievert, Henning, Zwischen arabischer Provinz und Hoher Pforte: Beziehungen, Bildung und Politik des osmanischen Bürokraten Rāġb Mehmed Paşa (st. 1763) (Würzburg: Ergon, 2008).

Stewart, Columba, "An Update on the Digitization and Cataloging Work of the Hill Museum and Manuscript Library (HMML)," Christian Orient 8 (2017):153-170.

Veinstein, Gilles, "Introduction," in Mehmed efendi: Le Paradis des infidèles: Relation de Yirmisekiz Çelebi Mehmed efendi, ambassadeur ottoman en France sous la Régence, translated by J.-C. Galland (Paris: Maspero, 1981), 7-51.

Vrolijk, Arnoud, Bringing a Laugh to a Scowling Face: A Study and Critical Edition of the "Nuzhat al-nufūs wa-muḍik al-'abūs" by 'Alì Ibn Sūdūn al-Bashbughāwì (Cairo 810/1407-Damascus 868/1464) (Leiden: Brill, 1998).

Walbiner, Carsten-Michael, "Die Protagonisten des frühen Buchdrucks in der arabischen Welt," in Das gedruckte Buch im Vorderen Orient, ed. U. Marzolph (Dortmund: Verlag für Orientkunde, 2002), 128-141.

Id., "Monastic Reading and Learning in Eighteenth-Century Bilād al-Šām: Some Evidence from the Monastery of al-Šuwayr (Mount Lebanon)," Arabica 51.4 (2004): $462-477$. 